\title{
PENINGKATAN KUALITAS PEMBELAJARAN KIMIA BAHAN ALAM MELALUI METODE PENGENALAN POLA
}

\author{
Nurbaity \\ FMIPA Universitas Negeri Jakarta (e-mail: nurbaity47@gmail.com; \\ HP. 081310581409)
}

\begin{abstract}
Improving the Quality of the Natural Chemical Substance Lesson through the Pattern Recognizing Method. This study aims to improve the quality of the natural chemical substance lesson through the pattern recognizing method. This study was an action research study consisting of two cycles, each of which involved three meetings. The first cycle presented the polyketide topic and the second cycle the terpenoid topic. The instruments were questionnaires, observation sheets, and evaluation sheets. The final stage of the second cycle showed that: 1) the quality of the assignments involving natural substances and the number of chemical found in the references improved, which made it easier to move to further steps, 2) the students' activities and participation increased, indicated by the group presentation in which each group had a chance to raise questions, 3) the quality and quantity of questions, especially high level ones, increased, and all of them were written and submitted, and 4) the students' learning achievement improved, indicated by the percentage of students achieving scores above 60 (84\%).
\end{abstract}

Keywords: natural chemical substance, pattern recognizing method

\section{PENDAHULUAN}

Dalam proses pembelajaran, seringkali dihadapkan pada masalah yang berkaitan dengan kualitas pembelajaran. Kualitas pembelajaran bergantung pada kemampuan dosen/ guru sebagai pendidik dalam menyiapkan kegiatan pembelajaran yang baik sehingga dapat dicapai tujuan pembelajaran secara efektif dan efisien. Untuk mencapai tujuan tersebut, dalam kegiatan pembelajaran terdapat dua aspek penting yang harus diperhatikan. Pertama, aspek proses belajar, yakni sejumlah pengalaman intelektual, emosional, dan fisik pada diri siswa. Kedua, aspek hasil belajar, yakni perubahan perilaku pada diri siswa (Dimyati,2006:136). Bertitik tolakpada pendapat tersebut, tujuan pokok penyelenggaraan kegiatan pembelajaran secara operasional adalah membelajarkan siswa agar mampu memproses dan memperoleh pengetahuan, keterampilan dan sikap bagi dirinya sendiri. Oleh karena itu, untuk meningkatkan kualitas pembelajaran selama kegiatan belajar mengajar, dosen/guru diharapkan merancang pengalaman belajar dan mencari model mengajar yang sesuai dengan 
karakteristik materi dan tujuan pembelajaran.

Kimia bahan alam merupakan bagian terpenting dari ilmu kimia organik yang mempelajari berbagai jenis senyawa dari sumber-sumber organik, baik tumbuhan, hewan, maupun mikroorganisme. Tujuan matakuliah Kimia Bahan Alam adalah agar mahasiswa mampu memahami proses terjadinya senyawa organik dalam makhluk hidup, khususnya senyawa golongan metabolit sekunder dan mengerti kerangka strukturnya, sifat kimia, dan aktivitas biologisnya. Senyawa-senyawa bahan alam ini tergolong metabolit sekunder yang berasal dari metabolit primer. Dalam perkembangan kimia bahan alam, terutama tertuju pada pembentukan struktur dan menyelidiki sifat-sifat metabolit sekunder seperti terpenoid, poliketida, flavonoid, steroid, dan alkoloid, melakukan pemisahan, memurnikan, dan akhirnya menganalisis senyawa-senyawa yang dihasilkan dari sel-sel hidup, serta menentukan struktur molekul dari senyawa-senyawa yang dihasilkan. Struktur molekul dari senyawa-senyawa tersebut mempunyai variasi yang luas. Senyawa-senyawa kimia bahan alam mempunyai polapola tertentu, keteraturan ditinjau dari segi kimia organik, dari golongan senyawa bahan alam tertentu dapat digunakan untuk mengembangkan pola berpikir yang terarah, sistematik, dan logis.

Berdasarkan hasil angket tentang pelaksanaan proses pembelajaran kimia bahan alam, mahasiswa menyatakan bahwa metode yang digunakan selama ini belum sesuai dengan yang diinginkan $(75 \%)$, penyampaian materi belum sistematis $(78,9 \%)$, materi terlalu banyak $(65 \%)$ sehingga kesulitan dalam mempelajari kimia bahan alam (63,1\%). Menyadari akan ciri-ciri kimia, khususnya kimia bahan alam yang dikemukakan di atas, dosen perlu mencari metode mengajar yang sesuai dengan karakteristik materi dan tujuan pembelajaran.

Salah satu metode pembelajaran kimia yang dapat membantu dosen dalam pencapaian tujuan pembelajaran dan meningkatkan kualitas pembelajaran kimia bahan alam adalah metode pengenalan pola. Metode pengenalan pola dalam pengembangan kimia didasarkan kepada hipotesis bahwa ilmu kimia mempunyai lebih dari sekedar struktur ilmu, tetapi diakui mempunyai pola sejumlah fakta unsur-unsur serta hubungannya dalam sistem periodik. Semua itu terdapatdi alam, semua itu objektif dan sah untuk segala situasi belajar (Tresna S.,1988:101). Di samping pola untuk unsur-unsur dalam sistem periodik pola serupa, dimungkinkan pula dipunyai oleh senyawa-senyawa kimia, khususnya senyawa bahan alam. Jumlah variabel di sini lebih besar dan jumlah kombinasi yang dimungkinkan amat banyak.

Pokok pikiran mempelajari kimia melaluipengenalan pola dilakukan dengan mendorong mahasiswa untuk mencoba mempelajari senyawa-senyawa dan reaksi kimia dengan cara yang lebih terorganisasi dan lebih bebas untuk mencapai tingkat kognitif yang lebih tinggi melalui proses ber- 
pikir tingkat tinggi. Menurut Lauren Renick(Arends, 2007:44), berpikir tingkat tinggi melibatkan nuanced judgment dan interpretasi, self regulation proses-proses berpikir, dan imposing meaning (menentukan makna), menemukan struktur dalam sesuatu yang tampak tidak beraturan, dan bersifat kompleks.

Model pengenalan pola dalam pembelajaran kimia mempunyai beberapa keuntungan, antara lain: (1) mengembangkan kemampuan mahasiswa untuk mengorganisasaikan data, menemukan dan menggolongkan parameter, pelacakan keteraturan, sistem dan pola, menggunakan berbagai sumber data dan menilai serta membandingkan; (2) memotivasi mahasiswa dengan jalan mencari informasi secara mandiri, produktif dalam pelacakan keteraturan organisasi data; dan (3) mahasiswa dapat mengorganisasikan belajar pada proses kognitif yang lebih tinggi, seperti tingkat menganalisis, mengevaluasi dan menciptakan.

Sebelum mata kuliah kimia bahan alam dipelajari, mahasiswa telah belajar tentang senyawa-senyawa kimia, struktur kimia yang jumlah dan variasinya sangat banyak, yang mem- punyai sifat-sifat fisika, sifat kimia, mekanisme reaksi kimia yang terjadi dalam makhluk hidup, biosintesa, serta manfaatnya. Berdasarkan karakteristik kimia bahan alam, penggunaan metode pengenalan pola diharapkan dapat meningkatkan kualitas pembelajaran kimia bahan alam sehingga dapat membantu mahasiswa dalam meningkatkan proses dan hasil belajar mereka.

Kualitas pembelajaran erat kaitannya dengan penggunaan metode mengajar yang optimal untuk mencapai tujuan pembelajaran. Hal ini berarti untuk mencapai kualitas pembelajaran yang tinggi, materi perkuliahan harus diorganisasi dengan strategi pengorganisasian yang tepat. Selanjutnya, materi disampaikan kepada mahasiswa dengan strategi penyampaian yang tepat pula. Pembelajaran harus mampu membuat materi yang diajarkan menarik dan tidak sebaliknya sehingga akan mempengaruhi proses dan hasil belajar mahasiswa.

Pelaksanaan belajar melalui pengenalan pola dapat dilihat pada langkah-langkah di bawah ini (Tresna S., 1988:101-104). 
Tabel 1. Langkah-langkah Belajar melalui Pengenalan Pola

\begin{tabular}{|c|c|}
\hline LANGKAH & \\
\hline $\begin{array}{l}\text { Pengumpulan data con- } \\
\text { toh: data tentang struk- } \\
\text { tur, reaksi, sifat senyawa } \\
\text { untuk lingkup batas. }\end{array}$ & $\begin{array}{l}\text { Pencarian data, mula-mula terbimbing, kemudian bebas, } \\
\text { dalam berbagai sumber; buku, jurnal, monograf, dan se- } \\
\text { bagainya. }\end{array}$ \\
\hline $\begin{array}{l}\text { Analisa data, penentuan } \\
\text { kriteria sebagai tetapan } \\
\text { dan variabel. }\end{array}$ & $\begin{array}{l}\text { Memperbandingkan data dapat melihat penyimpangan. } \\
\text { Siswa menentukan ketelitian menurut kualitas sumber, } \\
\text { dan perincian data berikutnya untuk pengecekan. } \\
\text { Dalam suatu pendekatan analisis ditentukan tetapan dan } \\
\text { variabel serta antar hubungan. }\end{array}$ \\
\hline $\begin{array}{l}\text { Penentuan urutan hierar- } \\
\text { ki kriteria, dari yang } \\
\text { umum menuju khusus. } \\
\text { Mulai membangun struk- } \\
\text { tur pohon yang akan di- } \\
\text { lengkapi dalam langkah } \\
\text { berikutnya. }\end{array}$ & $\begin{array}{l}\text { Siswa mengembangkan kemampuan untuk menganalisis } \\
\text { struktur, bukan menghafal struktur. } \\
\text { Siswa juga mengenal sejumlah data yang minimum } \\
\text { diperlukan untuk analisis struktur. } \\
\text { Mengembangkan kemampuan dan mengevaluasi data } \\
\text { berdasarkan sifat-sifat umum dan khusus untuk mem- } \\
\text { bangun struktur pohon. }\end{array}$ \\
\hline $\begin{array}{l}\text { Merancang matriks untuk } \\
\text { berbagai kombinasi krite- } \\
\text { ria yang mungkin. }\end{array}$ & $\begin{array}{l}\text { Dalam suatu pendekatan analisis siswa berusaha menen- } \\
\text { tukan pola untuk setiap pohon. } \\
\text { Hal ini akan mendukung sintesis data, hipotesis untuk } \\
\text { meramal. } \\
\text { Perumusan pengetahuan lebih terorganisasi dan pengem- } \\
\text { bangan pemikiran abstrak didukung. }\end{array}$ \\
\hline $\begin{array}{l}\text { Mensahihkan pola ran- } \\
\text { cangan }\end{array}$ & $\begin{array}{l}\text { Siswa membangun matriks untuk merancang pohon un- } \\
\text { tuk membuktikan apakah kriteria ditentukan secara } \\
\text { tepat. } \\
\text { Hal ini memungkinkan siswa mengenal gambaran yang } \\
\text { lebih jelas perihal antar hubungan data, dan membawa } \\
\text { keteraturan lebih banyak kepada pengetahuanya. } \\
\text { Membangun pohon dan belajar struktur linier dan } \\
\text { polidimensi juga membantu pendidikan penggunaan } \\
\text { komputer dalam ilmu kimia. }\end{array}$ \\
\hline $\begin{array}{l}\text { Menggunakan pola untuk } \\
\text { meramal. }\end{array}$ & $\begin{array}{l}\text { Siswa mendiskusikan apa yang masih kosong dalam } \\
\text { matriks dan pola. } \\
\text { Mula-mula mencari informasi baru kimia dalam berbagai } \\
\text { sumber. Kemudian mempelajari senyawa/reaksi tertentu } \\
\text { dari segi stereokimia, penggunaan model, cara-cara } \\
\text { biosintesis, termodinamika, atau kinetika, untuk men- } \\
\text { duga kemungkinan kehadiran senyawa/reaksi di alam } \\
\text { atau kemungkinan secara sintesis. } \\
\text { Siswa terlibat dalam penelitian, merancang jalan meng- } \\
\text { ikuti hasil penelitian, dan membangun pola menuju pe- } \\
\text { nyelesaian. Metode ini mendukung penyusunan hipotesa } \\
\text { dan rancangan penelitian lanjutan. }\end{array}$ \\
\hline
\end{tabular}


Revisi taksonomi Bloom (Anderson, et al, 2001:28) diberi nama taksonomi untuk belajar, mengajar, dan mengases (taxonomy for learning, teaching. dan asessing). Taksonomi ini bersifat dua dimensi. Pertama, dimensi pengetahuan (pengetahuan faktual, konsep, prosedur, dan metakognitif). Kedua, dimensi proses kognitif (cara berpikir) berisi domain kognitif yang dikategorikan ke dalam 6 jenjang kemampuan, yaitu: 1) mengingat, berarti mengambil informasi yang relevan dari ingatan jangka panjang; 2) memahami, berarti mengonstruksikan makna dari berbagai pesan instruksional; 3) menerapkan, berarti melaksanakan atau menggunakan suatu prosedur; 4) menganalisis, berarti menguraikan suatu materi ke dalam bagian konstituen dan menentukan bagaimana hubungan bagian yang satu dengan bagian yang lain, kemampuan jenjang analisis ini menunjukkan tingkat intelektual yang lebih tinggi daripada kemampuan jenjang pemahaman maupun penerapan karena merupakan akumulasi kemampuan pengetahuan, pemahaman dan aplikasi; 5) mengevaluasi, adalah kemampuan untuk memberikan keputusan berdasarkan standar dan criteria, yang meliputi kemampuan memeriksa (checking), memutuskan (judging), dan mengkritik(critiquing); 6) menciptakan, adalah kemampuan untuk meletakkan unsur-unsur untuk membentuk hubungan atau keseluruhan fungsi, mengorganisasikan kembali unsur ke dalam peta atau struktur yang baru. Mengevaluasi dan menciptakan berarti membuat judment berdasarkan kriteria dan menyatukan berbagai elemen untuk membentuk sebuah pola atau struktur baru (Anderson, et al. 2001:32).

Atas dasar uraian di atas, pembelajaran kimia bahan alam melalui model pengenalan pola dengan mengaplikasikan langkah-langkah pelaksanaannya diharapkan dapat meningkatkan kualitas pembelajaran kimia dalam proses maupun hasil belajar.

\section{METODE}

Penelitian ini merupakan penelitian tindakan kelas yang terdiri atas dua siklus. Rancangan penelitian ini mengikuti dasar penelitian tindakan kelas model dari David Kember (2000: 26) yang berbentuk spiral dan mengikuti siklus, mulai dari tahap perencanaan (planing), tindakan (acting), observasi (observing), dan refleksi (reflecting). Hasil refleksi siklus I sebagai dasar untuk merencanakan tindakan pada siklus berikutnya sehingga diperoleh keberhasilan sesuai dengan indikator yang ditentukan.

Penelitian dilaksanakan di Jurusan Kimia FMIPA Universitas Negeri Jakarta (UNJ) pada semester ganjil tahun ajaran 2005-2006 melalui dua siklus. Subjek penelitian adalah mahasiswa Program Studi Pendidikan Kimia yang mengambil matakuliah Kimia Bahan Alam sejumlah 26 orang. Prosedur penelitian dimulai dari perencanaan tindakan pada siklus I dengan kegiatan: (1) kegiatan pendahuluan, membagi angket pada mahasiswa untuk memperoleh informasi dan persepsi mahasiswa tentang pelaksanaan perkuliahan kimia bahan alam, 
danharapan mahasiswa terhadap perkuliahan tersebut; (2) menganalisis hasil angket tersebut; (3) mengemukakan rencana mengatasi masalah dan metode yang akan dilakukan dalam perkuliahan kimia bahan alam; (4) menentukan tujuan, materi, dan merancang skenario pembelajaran yang akan dilaksanakan dalam perkuliahan; (5) menyiapkan perangkat pembelajaran yang diperlukan.

Pelaksanaan tindakan berdasarkan rencana yang sudah disepakati. Pembelajaran menggunakan metode pengenalan pola dengan kegiatan berdiskusi dalam kelompok kecil (4-5 orang) mengerjakan tugas yang telah ditentukan, mempresentasikan tugas dan berdiskusi. Selama tindakan dilakukan pengamatan menggunakan lembar pengamatan untuk mengevaluasi keaktifan mahasiswa dan menganalisis pertanyaan-pertanyaan yang dijukan selama diskusi serta memberi tes hasil belajar kemampuan kognitif untukmengetahui daya serap atau penguasaan materi pada siklus I. Selanjutnya, dilakukan refleksi dengan cara menganalisis hasil pengamatan selama pembelajaran dari lembar observasi maupun catatan lapangan, dan jawaban tes tertulis dari mahasiswa. Kemudian, mengevalusi kelemahan dan kekuatan yang ada pada siklus I dan mencari alternatif upaya mengatasi kelemahan tersebut.

Kriteria keberhasilan yang ingin dicapai pada penelitian ini adalah adanya peningkatan kualitas pembelajaran kimia bahan alam dengan metode pengenalan pola. Indikator kualitas pembelajaran berupa peningkatan pe- mahaman mahasiswa mengaplikasikan langkah-langkah pengenalan pola (hasil tugas kelompok), peningkatan keaktifan mahasiswa pada diskusi di kelas, peningkatan hasil belajar mahasiswa, khususnya kemampuan kognitif tingkat tinggi (menganalisis, mengevaluasi, dan berhipotesis untuk meramal).

Hasil refleksi dari siklus I digunakan sebagai dasar untuk merencanakan tindakan pada siklus II yang dimulai dengan (1) menentukan strategi perkuliahan berdasarkan hasil refleksi; dan (2) menyiapkan materi, lembar pengamatan, serta instrumen tes untuk siklus II. Pelaksanaan tindakan dilakukan menggunakan metode yang telah disepakati, yaitu pengenalan pola. Selama pelaksanaan tindakan dilakukan pengamatanmenggunakan lembar pengamatan untuk melihat aktivitas mahasiswa dan memberi tes tertulis untuk mengetahui penguasaan mahasiswa pada materi yang diberikan pada siklus II. Refleksi dilakukan dengan cara menganalisis hasil pengamatan dari lembar observasi dan catatan lapangan, serta hasl tes tertulis dari mahasiswa, mengevaluasi kelemahan dan kekuatan yang ada, dan mencari jalan keluar untuk mengatasi kelemahan tersebut.

Instrumen penelitian terdiri dari kuesioner atau angket analisis kebutuhan tentang persepsi mahasiswa pada perkuliahan kimia bahan alam, lembar penilaian hasil tugas kelompok, lembar pengamatan pelaksanaan pembelajaran, lembar penilaian pelaksanaan presentasi dan diskusi, serta catatan lapangan, instrumen tes hasil 
belajar setiap akhir siklus, dan angket untuk menjaring pendapat mahasiswa pada akhir siklus tentang pembelajaran kimia bahan alam menggunakan metode pengenalan pola. Analisis data yang digunakan adalah analisis deskriptif kualitatif .

\section{HASIL DAN PEMBAHASAN}

Hasil penelitian setiap siklus dapat dikemukakan sebagai berikut.

\section{SIKLUS I}

\section{Perencanaan}

Dari hasil angket analisis kebutuhan pada mahasiswa dan hasil wawancara menunjukkan mahasiswa mengalami kesulitan mempelajari kimia bahan alam karena ruang lingkup materi terlalu banyak, penyajian tidak sistematis dan metode yang digunakan belum sesuai dengan harapan. Mahasiswa kurang termotivasi dalam mengikuti perkuliahan, terlihat dari aktifitas dan kesiapan mereka pada waktu diskusi dan tanya jawab pada saat pembelajaran berlangsung.

Dalam upaya meningkatkan kualitas pembelajaran kimia bahan alam, agar mahasiswa mampu memahami proses terjadinya senyawa organik dalam makhluk hidup, khususnya metabolit sekunder, mengerti kerangka strukturnya, sifat kimia, dan aktifitas biologisnya. Perlu dicari alternatif metode pembelajaran yang sesuai dengan karakteristik materi dan tujuan pembelajaran. Salah satu metode yang sesuai dan dapat memenuhi harapan mahasiswa dalam mempelajari kimia bahan alam adalah metode pengenalan pola. Metode ini disepakati untuk diterapkan dalam pembelajaran metabolit sekunder. Materi yang dipilih adalah metabolit sekunder golongan poliketida. Pada tahap perencanaan dilakukan langkah-langkah sebagai berikut.

Membuat skenario pembelajaran yang menarik dan mudah dipaha$\mathrm{mi}$, yaitu dengan cara menjelaskan dan memberi contoh langkah-langkah pengenalan pola untuk membuat tugas yang akan dikerjakan dalam kelompok meliputi: (1) pengumpulan data, mencari data dan menemukan berbagai struktur senyawa-senyawa kimia golongan poliketida dari literatur atau jurnal minimal 10 data; (2) analisa data, menganalisis struktur senyawa kimia dari data yang diperoleh sehingga dapat menyimpulkan bahwa senyawa-senyawa poliketida yang ditemukan mempunyai bagian umum yang tetap atau menentukan kriteria sebagai tetapan dan variable; (3) penentuan urutan hirarki kriteria, dari yang umum menuju khusus, yakni yang lebih banyak dipunyai oleh poliketida, yang lebih spesifik untuk sekumpulan rumus, mengembangkan dan mengevaluasi data berdasarkan sifat umum dan khusus untuk membangun struktur pohon; (4) merancang matrik untuk berbagai kombinasi kriteria yang mungkin sehingga dapat menentukan pola untuk setiap pohon; (5) mensahihkan pola rancangan, mahasiswa akan menemukan setiap matrik dengan koleksi data; (6) menggunakan pola meramalkan kemungkinan adanya 
senyawa-senyawa golongan policetida yang belum ditemukan. Apakah sifat-sifat senyawa poliketida yang diperoleh dari hasil kombinasi yang mungkin? Bagaimanakah sifat bioaktifitas senyawa-senyawa tersebut? Bagaimanakah biosintesisnya?

Mengerjakan tugas dalam kelompok kecil (setiap kelompok terdiri 4-5 mahasiswa) diluar jam tatap muka (tugas terstruktur).

Setiap kelompok mempresentasikan hasil tugas kelompok di depan kelas dan mendiskusikannya. Tugas setiap kelompok dikumpulkan untuk dinilai. Selanjutnya, membuat lembar observasi dan instrumen penilaian diskusi kelompok, instrumen penilaian hasil tugas kelompok, serta instrumen tes akhir siklus.

\section{Pelaksanaan Tindakan}

Pelaksanaan pembelajaran menggunakan metode pengenalan pola berdasarkan 6 langkah yang diawali dengan mengerjakan tugas pengenalan pola pada materi pokok poliketida dalam kelompok kecil (4-5 orang). Pada pelaksanaan diskusi, salah seorang anggota kelompok memapar- kan hasil tugas kelompok, mahasiswa yang lain menanggapi, dan mengajukan pertanyaan yang berkaitan dengan materi yang dibahas. Kelompok penyaji menjawab pertanyaan. Dosen sebagai fasilitator mengawasi diskusi yang berjalan dan membantu memberi arahan dan masukan dalam menjawab pertanyaan. Anggota tim peneliti yang lain sebagai observer, mengamati jalannya diskusi menggunakan lembar observasi dan catatan lapangan. Pada akhir diskusi, dosen dan mahasiswa menyimpulkan tugas yang telah dikerjakan. Selanjunya, mahasiswa mengerjakan tes akhir siklus.

\section{Observasi}

Observasi siklus I pada pelaksanaan pembelajaran kimia bahan alam dengan metode pengenalan pola dapat dikemukakan sebagai berikut.

Pertama, pengamatan pada pemahaman mengaplikasikan langkahlangkah pengenalan pola pada materi poliketida ( hasil kerja kelompok kecil yang dipresentasikan).

Langkah 1: Pengumpulan data, pada contoh berikut ini ditemukan 22 data struktur senyawa kimia golongan poliketida. 


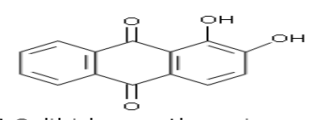

1, 2 di hidroxyanthractui none
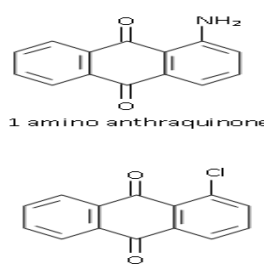

1 chal oroanthracisi none
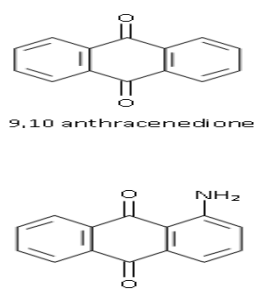

1 aming 4 hydroxyanthraquingme

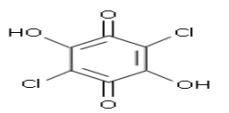

2.5 dichloro-3.6 dihydrom- Pbenzagui nane
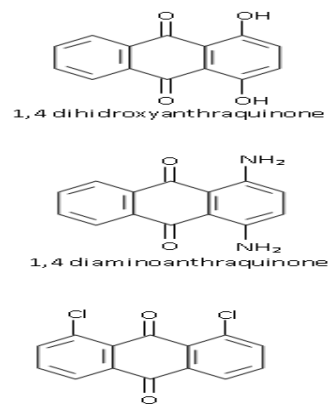

1. a dichlaroanthractuinane
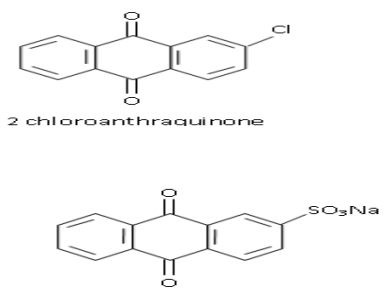

9,10 anthraquinone 2 sulfanic Na acid

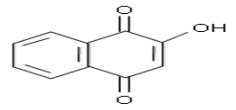

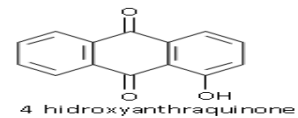
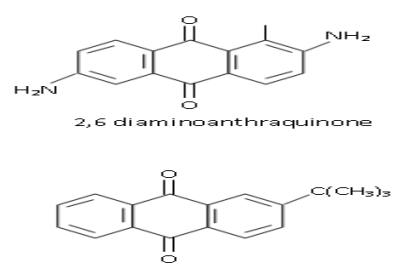

2 tert-butylanthractui none

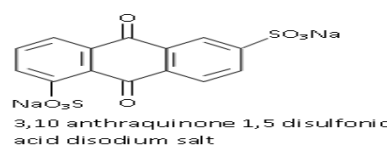

acid disadi tum salt
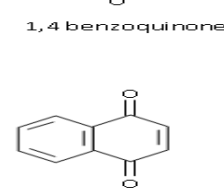
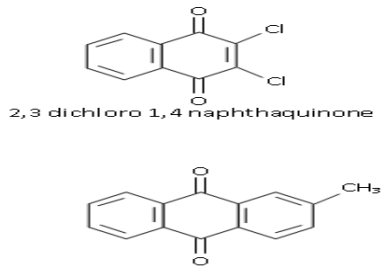<smiles>CCC1=CC=[Te]c2ccccc21</smiles>

2 methyl 1, 4 maphthaquingme

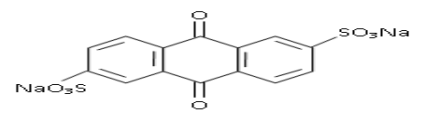

9,10 anthraquinane 2,6 disulf anic aciddisadium salt
Langkah 2: Analisis data, penentuan tetapan dan variabel. Berdasarkan hasil analisis dari rumus kimia di atas mahasiswa sudah dapat menyimpulkan bahwa semua poliketida mempunyai bagian umum yang tetap, yaitu cincin benzokuinon.

Rumus umum:<smiles>O=C1C=CC(=O)C=C1</smiles>

Langkah 3: Penentuan urutan hierarki kriteria, membangun pohon poliketida turunan quinone mempunyai sistem cincin sebagai berikut. 


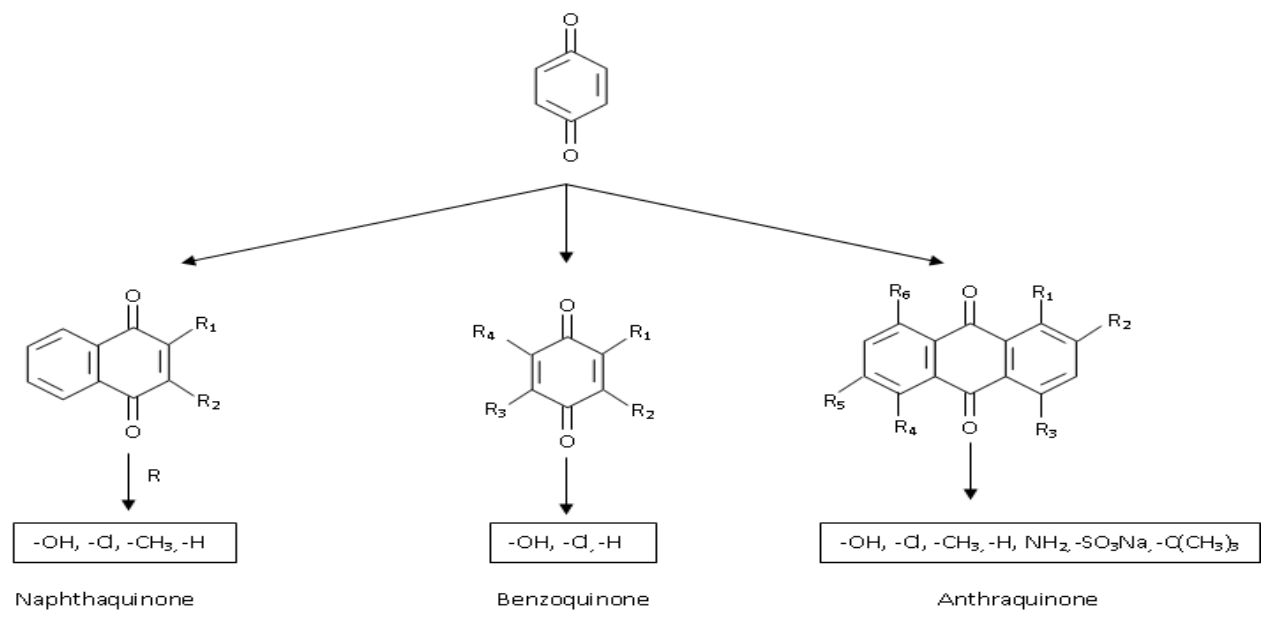

Mahasiwa meramalkan kriteria mana yang lebih umum, yaitu yang lebih banyak dipunyai oleh poliketida, yang lebih spesifik untuk sekumpulan rumus. Disimpulkan bahwa poliketida mempunyai sistem cincin satu (benzoquinon); cincin dua (napthaquinon) dan cincin tiga (anthraquinon). Seperti terlihat pada senyawa di atas variasi $R$ pada masing-masing cincin mempunyai banyak kemungkinan kombinasi.

Langkah 4: merancang matrik untuk kombinasi yang mungkin. Kemungkinan matrik untuk dua cincin naphthaquinone.

\begin{tabular}{|c|c|c|c|c|}
\hline $\mathrm{R}_{1} \mathbb{R}_{2}$ & $\mathrm{OH}$ & $\mathrm{Cl}$ & $\mathrm{CH}_{3}$ & $\mathrm{H}$ \\
\hline $\mathrm{OH}$ & $\mathrm{K}_{1}$ & $\mathrm{~K}_{2}$ & $\mathrm{~K}_{3}$ & $\mathrm{~K}_{4}$ \\
\hline $\mathrm{Cl}$ & $\mathrm{K}_{5}$ & $\mathrm{~K}_{6}$ & $\mathrm{~K}_{7}$ & $\mathrm{~K}_{8}$ \\
\hline $\mathrm{CH}_{3}$ & $\mathrm{~K}_{9}$ & $\mathrm{~K}_{10}$ & $\mathrm{~K}_{11}$ & $\mathrm{~K}_{12}$ \\
\hline $\mathrm{H}$ & $\mathrm{K}_{13}$ & $\mathrm{~K}_{14}$ & $\mathrm{~K}_{15}$ & $\mathrm{~K}_{16}$ \\
\hline
\end{tabular}

Dari matrik tersebut, diperoleh 16 jenis kombinasi senyawa poliketida.

Langkah 5: pensahihkan pola rancangan kombinasi poliketida (contoh)
K4 = 2-hidroksi Napthaquinone

K6 = 2,3-Dikloro aphthaquinone

K12=2-Metil Naphthaquinone

K16=Naphthaquinone

Langkah 6:menggunakan pola untuk meramal. Adakah poliketida dari semua kombinasi pada contoh di atas terdapat di alam? Bagaimana sifat-sifat senyawa tersebut? Bagaimana biosintesisnya?

Penilaian tugas kelompok ini berdasarkan pada langkah-langkah pengenalan pola seperti berikut. Pertama, pengumpulan data, jumlah data dari berbagai struktur senyawa poliketida yang ditemukan dari berbagai literatur atau jurnal. Dari 6 kelompok, 2 kelompok menemukan data lebih dari 10 rumus senyawa, bahkan ada satu kelompok menemukan 22 data, 4 kelompok lainnya di bawah 10. Kedua, analisis data, penentuan kriteria sebagai tetapan dan variabel. Bagaimana mahasiswa menganalisis rumus senyawa-senyawa yang ditemukan sehingga dapat menyimpulkan bahwa golongan poliketida ini mempu- 
nyai bagian umum yang tetap. Berdasarkan hasil tugas kelompok, secara umum mahasiswa telah mampu menganalisis dan menyimpulkan bagian umum yang tetap dari rumus senyawa-senyawa yang ditemukan. Ketiga, penentuan urutan hierarki kriteria membangun pohon. Semua kelompok telah mampu menentukan kriteria tingkat tertinggi rumus umum yang telah ditetapkan. Keempat, merancang matrik untuk berbagai kombinasi kriteria yang mungkin. Pada tahap ini, mahasiswa sudah mampu berpikir tingkat tinggi, yaitu menghasilkan hipotesis untuk meramal. Pada umumnya, semua kelompoktelah memahami dan dapat merancang matrik untuk kombinasi yang mungkin. Kelima, mensahihkan pola rancangan. Dari hasil tugas terlihat bahwa tidak semua kelompok dapat membuat bagaimana mensahihkan kombinasi dari matrik kombinasi yang mungkin, sebagian kelompok belum dapat menggunakan pola untuk meramal.

Berdasarkan kriteria penilaian hasil tugas pengenalan pola, 2 kelompok memperoleh nilai A, 2 kelompokmendapat nilai $\mathrm{B}$, dan 2 kelompok mendapat nilai C. Bila dikaji pada langkah-langkah dalam menyelesaikan tugas menggunakan metode pengenalan pola tersebut, mahasiswa telah memilikipengetahuan sebagaimana yang dikemukan oleh Thomas L. Good (1990:191), yaitu pengetahuan (1) deklaratif, adalah cara menerangkan pengetahuan yang benar; (2) pengetahuan prosedural adalah aturan-aturan dan aplikasi dari ilmu pengetahuan, termasuk mempelajari aturan-atur- an yang mempergunakan suatu kesatuan informasi yang lebih luas; (3) pengetahuan konseptual adalah pengetahuan yang meliputi mengkategorikan informasi yang berhubungan ke dalam ide yang teratur. Dari dimensi proses kognitif atau proses berpikir menurut Anderson telah mencapai proses berfikir tingkat tinggi.

Kedua, presentasi dan diskusi tugas kelompok. Berdasarkan lembar observasi, proses diskusi belum berjalan lancar, belum semua kelompok aktif bertanya, hanya 2 kelompok saja yang aktif bertanya. Dari kelompok yang aktif tersebut, hanya 1 atau 2 orang saja yang bertanya. Belum terlihat adanya pertanyaan-pertanyaan yangberkualitas atau pertanyaan tingkat tinggi. Terlihat dari pertanyaan yang diajukan mahasiswa hanya menanyakan apa nama senyawa kimia yang diramalkan, belum muncul pertanyaan mengapa dan bagaimana. Kelompok mahasiswa yang tidak presentasi terlihat pasif. Mereka belum termotivasi untuk bertanya. Keaktifan dan kerjasama mahasiswa terlihat dari kelompok yang presentasi, yaitu dari persiapan anggota kelompok dalam menampilkan tugas pengenalan pola yang sudah terlihat kemampuan mahasiswa dalam menyampaikan dan menjelaskan dengan menggunakan OHP, penggunaan bahasa, kualitas jawaban, walaupun ada beberapa jawaban yang belum sempurna. Dalam menjawab pertanyaan, tidak semua anggota kelompok terlihat aktif, hanya diwakili oleh 2 orang anggota kelompok saja. Berdasarkan catatan la- 
pangan, kelompokyang presentasi kurang menguasai materi yang dibahas.

Ketiga, hasil belajar mahasiswa pada siklus 1 dapat dilihat pada Tabel berikut.

Tabel 2. Hasil Belajar Mahasiswa pada Siklus I

\begin{tabular}{cc}
\hline Skor yang Dicapai & Pesen(\%) \\
\hline $80-100$ & 7.69 \\
$70-79$ & 19,23 \\
$60-69$ & 30,78 \\
$55-59$ & 26,92 \\
$<55$ & 15,38 \\
\hline
\end{tabular}

Berdasarkan data di atas, hasil belajar mahasiswa yang mendapat skor lebih besar dari 70 mencapai 26,92\% dan skor di bawah 60 mencapai $42,30 \%$.

Keempat, respon mahasiswa terhadap pelaksanaan pembelajaran dengan metode pengenalan pola.

Berdasarkan hasil wawancara dengan beberapa orang mahasiswa, penjelasan awal perkuliahan memberi gambaran bagi mahasiswa tentang ruang lingkup bahan alam dan keragaman senyawa bahan alam serta zat-zat aktif yang tergolong metabolit sekunder yang terdapat pada bahan alam. Dengan metode pengenalan pola yang dilaksanakan ini, mahasiswa sebagian besar tertarik karena pola-pola struktur dari senyawa metabolit sekunder dapat membantu pengelompokan senyawa bahan alam dan membantu dalam mempelajari kimia bahan alam. Mengenai tugas yang diberikan, terdapat beberapa mahasis- wa yang merasa tugasnya terlalu berat karena tidak cukup waktu untuk mencari literatur dan mengerjakannya dalam satu minggu. Hal ini dapat terlihat dari hasil tugas kelompok mereka yang hanya menggunakan satu literatur saja.

Berdasarkan data tersebut di atas dan evaluasi indikator keberhasilan pada siklus I, dapat dikemukakan halhal sebagai berikut.

Pertama, langkah-langkah pengenalan pola sudah cukup dipahami, walaupun masih belum sempurna karena pada umumnya data yang dikumpulkan dari literatur masih minim.

Kedua, belum semua anggota kelompok aktif dalam diskusi kelas. Pertanyaan-pertanyan yang muncul masih tergolong pertanyan tingkat rendah.

Ketiga, data hasil belajar mahasiswa masih belum mencapai apa yang diharapkan karena $42,30 \%$ mahasiswa memperoleh nilai $<60$. Hal ini berarti masih cukup banyak mahasiswa yang belum memahami konsep yang dipelajari.

Keempat, respon mahasiswa terhadap pengunaan metode pengenalan pola positif sehingga sebagian besar mahasiswa antusias mengikuti perkuliahan.

\section{Refleksi}

Tim peneliti pada tahap refleksi menganalisis hasil observasi selama pembelajaran. Hasil observasi seperti tersebut di atas, selanjutnya akan digunakan sebagai dasar pada tahap analisis dan refleksi untuk perbaikan 
siklus II. Perbaikan siklus II dimaksudkan untuk pencapaian indikator yang dapat dikemukakan sebagai berikut. Pertama, peningkatan kualitas tugas kelompok. Pada awalnya, hasil tugas kelompok belum memuaskan karena belum semua kelompok memahami 6 langkah-langkah pengenalan pola yang dijelaskan. Oleh karena itu, mereka disarankan menambah jumlah data senyawa kimia minimal 15 . Kedua, peningkatan aktivitas dan partisipasi semua anggota kelompok dalam diskusi, terlihat aktifitas mahasiswa sangat kurang. Ketiga, peningkatan kualitas pertanyaan yang diajukan, jumlah pertanyaan masih sangat sedikit dan kualitas pertanyaan masih tergolong tingkat rendah. Keempat, peningkatan hasil belajar.

\section{SIKLUS II}

\section{Perencanaan}

Berdasarkan refleksi siklus I, pada siklus II ini dilakukan beberapa perbaikan. Aspek-aspek yang belum muncul pada siklus I atau belum mencapai target, diharapkan diamati dan meningkat pada siklus II. Pada siklus II, materi pokok yang dipilih adalah terpenoid. Materi yang akan dipresentasikan sebagai tugas kelompok diinformasikan seminggu sebelumnya. Untuk meningkatkan kualitas tugas, setiap kelompok diwajibkan mengumpulkan data senyawa kimia golongan terpenoid minimal 15, dan menambah kajian teori yang berkaitan dengan topik yang dipresentasikan. Setiap kelompok diberi kebebasan untuk memilih senyawa golongan terpenoid (monoterpen, sesquiterpen, diterpen, atau triterpen) sebagai topik tugas. Mahasiswa diharapkan dapat meningkatkan kemampuan menganalisis dan mengambil kesimpulan dari data yang ada untuk merancang dan menggunakan pola untuk meramal.

Untuk meningkatkan aktivitas atau partisipasi semua anggota kelompok, setiap kelompok yang mengkritisi diberi kesempatan bertanya secara terstruktur. Artinya, setiap kelompok diberi giliran dan mengajukan pertanyaan. Semua anggota kelompok yang presentasi harus aktif berpartisipasi dalam menjawab pertanyaan. Tugas setiap kelompok dikumpulkan untuk dinilai sesuai ketentuan yang telah ditetapkan berdasarkan langkah-langkah pengenalan pola.

Untuk meningkatkan kualitas pertanyaan yang diajukan pada waktu presentasi, pertanyaan yang disampaikan diusahakan harus pertanyaan tingkat tinggi. Pertanyaan yang akan diajukan ditulis terlebih dahulu. Pertanyaan tersebut akan dikumpul dan dinilai kualitas pertanyaannya. Pada waktu diskusi, dosen berpartisipasi membantu mahasiswa dalam menjawab pertanyaan, dan di akhir diskusi dilakukan tes hasil belajar untuk mengetahui pemahaman pada materi yang dibahas. Pada akhir siklus ini, dibagikan angket untuk mengetahui pendapat mahasiswa terhadap kegiatan pembelajaran.

\section{Pelaksanaan Tindakan}

Pelaksanaan pembelajaran menggunakan metode pengenalan pola berdasarkan 6 langkah diawali dengan 
mengerjakan tugas pengenalan pola pada materi pokok terpenoid dalam kelompok kecil (4-5 orang). Masingmasing kelompok mempresentasikan tugasnya. Pada pelaksanaan diskusi kelas salah seorang dari anggota kelompok memaparkan hasil tugas kelompoknya. Selesai presentasi, dibuka forum tanya jawab, kelompok yang lain menanggapidan mengajukan pertanyaan yang berkaitan dengan materi yang dibahas. Kelompokyang mengkritisi diberi kesempatan mengajukan pertanyaan secara bergiliran. Mahasiswa menanyakan bagaimana bisa menentukan rumus umum dari data senyawa terpenoid yang ada, bagaimana menentukan urutan hierarki untuk membangun pohon terpenoid, dan bagaimana menggunakan pola untuk meramalkan senyawa-senyawa terpenoid yang mungkin terdapat di alam, bagaimana mementukan sifatsifatnya, dan biosintesisnya. Kelompokpenyaji menjawab pertanyaan tersebut dengan menerangkan kembali langkah-langkah pengenalan pola, tetapi beberapa anggota kelompok yang mengkritisi belum puas dengan jawaban sehingga terjadi diskusi yang hangat antarkelompok maupun antarmahasiswa dalam kelompok. Dosen sebagai fasilitator mengawasi jalannya diskusi dan membantu memberi arahan dan penjelasan dalam menjawab pertanyaan. Anggota tim peneliti yang lain sebagai observer mengamati jalannya diskusi menggunakan lembar observasi dan catatan lapangan. Pada akhir diskusi, dosen bersama mahasiswa menyimpulkan hasil tugas terpenoid yang dipresentasikan. Selan- jutnya, mahasiswa mengerjakan tes akhir siklus dan mengisi angket untuk menegetahui pendapat mahasiswa tentang kegiatan pembelajaran kimia bahan alam.

\section{Observasi/Pengamatan}

Hasil observasi siklus II sesuai indikator dapat dikemukakan sebagai berikut.

Pertama, hasil tugas kelompok dengan materi pokok terpenoid. Berdasarkan kriteria penilaian yang telah ditentukan, dari 6 kelompok terdapat 3 kelompok mendapat nilai $\mathrm{A}$, dan 3 kelompok mendapat nilai $\mathrm{B}$, tidak ada kelompok yang mendapat nilai $\mathrm{C}$, seperti telihat pada Tabel 3. Kualitas tugas pada siklus II terlihat meningkat. Pada umumnya, semua kelompok mengerjakan tugas sudah baik, terutama terlihat dari jumlah data rumus kimia terpenoid yang ditemukan dari literatur yang sudah mencapai target minimal, yaitu 15 senyawa. Dalam hal ini, terjadi peningkatan bila dibandingkan dengan siklus I. Dalam menganalisis data, sudah terlihat kemampuan menetapkan dan menentukan variabel serta hubungan antarvariabel. Artinya, mahasiswa sudah mampu membandingkan antara data senyawa kimia yang telah ditemukan dan mengembangkan kemampuan untuk mengalisis struktur untuk menentukan pola yang akan mendukung kemampuan mensintesis data, serta berhipotesis untuk meramal. 
Tabel 3. Nilai Tugas Kelompok Siklus I dan Siklus II

\begin{tabular}{ccc}
\hline $\begin{array}{c}\text { Nilai Tugas } \\
\text { Kelompok }\end{array}$ & Siklus I & Siklus 2 \\
\hline A & 2 kelompok & 3 kelompok \\
B & 2 kelompok & 3 kelompok \\
C & 2 kelompok & - \\
\hline
\end{tabular}

Kedua, aktifitas dan partisipasi mahasiswa dalam diskusi kelas pada waktu peresentasi.

Pada waktu diskusi kelas, semua kelompok aktif dan ikut berpartisipasi. Hal ini ditunjukkan setiap kelompok yang selalu ada anggotanya yang mengajukan pertanyaan. Selama diskusi kelas berlangsung, terdapat 16 mahasiswa yang bertanya. Partisipasi mahasiswa meningkat jika dibandingkan dengan siklus I, yang hanya ada 4 mahasiswa yang bertanya. Suasana kelas terlihat kondusif, terjadi interaksi antarmahasiswa dan antara dosen dengan mahasiswa. Semua anggota kelompok yang presentasi ikut terlibat dalam menjawab pertanyaan.

Ketiga, kualitas pertanyan selama diskusi. Kualitas pertanyaan yang diajukan sudah meningkat. Pertanyaan yang muncul atau diajukan oleh mahasiswa dalam diskusi kelas tergolong pertanyaan tingkat tinggi, seperti pertanyaan mengapa dan bagaimana yang mengarah pada kemampuan berfikir menganalisis, mengevaluasi, dan meramalkan.

Keempat, hasil belajar mahasiswa pada siklus II. Data hasil belajar siklus 2 pada tabel 4 , terlihat skor mahasiswa di atas 70 mencapai $46,15 \%$ dan skor di bawah 60 mencapai 15,39\%. Berdasarkan analisis siklus I dan sik- lus II di atas menunjukkan adanya peningkatan kualitas pembelajaran kimia bahan alam.

Table 4. Hasil Belajar Mahasiswa pada siklus 2

\begin{tabular}{cc}
\hline Skor yang dicapai & Prosen(\%) \\
\hline $80-100$ & 7,69 \\
$70-79$ & 38,46 \\
$60-69$ & 38,46 \\
$55-59$ & 3,85 \\
$<55$ & 11,54 \\
\hline
\end{tabular}

Menurut data hasil observasi dan evaluasi indikator keberhasilan pada siklus II ini dapat dikemukakan halhal sebagai berikut.

Pertama, langkah-langkah pengenalan pola dalam mengerjakan tugas sudah dipahami dengan baik dan studi literatur sudah ada peningkatan. Jadi sudah ada peningkatan kualitas tugas, hal ini terlihat dari nilai tugas kelompok pada siklus I dan II. Dari hasil tugas kelompok, dapat dinilai kemampuan tingkat kognitif yang telah dicapai mahasiswa.

Kedua, aktifitas/partisipasi mahasiswa dalam diskusi kelas sudah ada peningkatan. Jika pada siklus 1 hanya ada 4 mahasiswa yang bertanya, pada siklus II meningkat menjadi 16 mahasiswa yang mengajukan pertanyaan. Suasana diskusi hidup karena terjadi interaksi antar mahasiswa, dan antara mahasiswa dengan dosen. Demikian juga dengan anggota kelompok yang presentasi, terlihat kerjasama dan keterlibatan semua anggota kelompok dalam menjawab pertanyaan.

Ketiga, kualitas pertanyaan ada peningkatan, bila pada siklus I pertanyan yang diajukan hanya tingkat ren- 
dah, seperti menanyakan nama senyawa kimia akan tetapi pada siklus II ini kualitas pertanyaan meningkat pada aspek kognitif tingkat tinggi seperti pertanyaan bagaimana menentukan rumus umum dari data yang diperoleh, dan merancang matrik untuk kombinasi yang mungkin berdasarkan pola dari struktur yang ada, yang jawabannya diperlukan kemampuan menganalisis, mengevaluasi, berhipotesis untuk meramal.

Keempat, peningkatan hasil belajar mahasiswa, dari data hasil belajar mahasiswa pada siklus I terlihat peningkatan pada siklus II. Mahasiswa yang mendapat nilai lebih besar dari 70 sebesar $26,92 \%$ pada siklus 1 dan $46,14 \%$ pada siklus II, dan nilai lebih kecil dari 60 pada siklus I sebesar 42,30\%, pada siklus II turun menjadi 15,39\%.

Kelima, respon mahasiswa terhadap metode pengenalan pola dalam pembelajaran kimia bahan alam.

Berdasarkan hasil angket bahwa belajar melalui pengenalan pola meningkatkan motivasi mahasiswa $(70 \%)$. Menemukan cara baru dalam mempelajari kimia bahan alam (70\%). Menemukan banyak contoh senyawa metabolit sekunder di alam (90\%). Dapat meramalkan senyawa-senyawa kimia bahan alam yang belum ditemukan (95\%). Melatih menganalisa data dan bukan menghafal data (80\%). Meningkatkan interaksi selama pembelajaran (70\%).

\section{Refleksi}

Analisis dan evaluasi hasil pencapaian indikator yang diharapkan untuk meningkatkan kualitas pembe- lajaran kimia bahan alam dengan metode pengenalan pola pada siklus II, yaitu pada hasil tugas terpenoid sudah terlihat peningkatan, pemahaman langkah-langkah pengenalan pola dan kemampuan mengaplikasikan dalam materi terpenoid sudah cukup bagus, sudah ada peningkatan mulai dari pengumpulan data, menganalisa data, membangun struktur pohon, merancang matriks, mensahihkan pola, dan menggunakan pola untuk meramal. Aktivitas dan partisipasi mahasiswa, serta kemampuan presentasipun meningkat. Kualitas pertanyaan sudah mencapai pertanyaan tingkat tinggi yang mengarah pada kemampuan menganalisis, mengevaluasi dan meramalkan. Hasil tes hasil belajar pada akhir siklus II ini juga meningkat, sebagian besar mahasiswa mendapat nilai di atas 60 mencapai 84,61\%.

Berdasarkan hasil yang telah dicapai untuk meningkatkan kualitas pembelajaran kimia bahan alam dengan metode pengenalan pola, maka tim peneliti memutuskan menghentikan pada siklus II.

\section{KESIMPULAN}

Metode pengenalan pola dapat meningkatkan kualitas pembelajaran kimia bahan alam. Berdasarkan hasil analisis data yang diperoleh dilihat pada pencapaian setiap indikator dapat dikemukakan sebagai berikut.

Pertama, kualitas tugas kelompok pengenalan pola sudah sesuai dengan yang diharapkan. Hal tersebut dapat dilihat dari kemampuan mahasiswa mengorganisasikan belajar pada tingkat kognitif yang lebih tinggi yang 
meningkatkan, seperti kemampuan menganalisa data, mengevaluasi data, mensintesis data dan berhipotesis untuk meramal serta keterampilan pemecahan masalah.

Kedua, peningkatan dan partisipasi semua angota kelompok dalam diskusi, terlihat dari aktivitas anggota kelompok dalam mengajukan pertanyaan, kualitas pertanyaan tergolong pertanyaan tingkat tinggi.

Ketiga, hasil belajar mahasiswa sudah mencapai target yang diharapkan, peningkatan rata-rata kelas dan persentase mahasiswa yang memperoleh nilai lebih besar dari 60 sebesar $84,61 \%$.

Keempat, model pembelajaran pengenalan pola dapat membuka cakrawala mahasiswa, dan model ini merupakan cara baru yang lebih sistematis dalam mempelajari kimia bahan alam sehingga dapat meningkatkan motivasi mahasiswa.

Berdasarkan butir-butir di atas, dapat disimpulkan bahwa penggunaan model pembelajaran pengenalan pola ini dapat meningkatkan kualitas pembelajaran kimia bahan alam.

\section{UCAPAN TERIMA KASIH}

Pada kesempatan ini perkenankan kami mengucapkan terima kasih kepada Direktur LPIU- Universitas Negeri Jakarta, yang telah memberi kesempatan kepada kami melaksanakan penelitian ini yang dibiayai oleh dana Program Due Like. Ucapan terima kasih juga kami sampaikan kepada Tim Reviewer LPIU Due Like yang telah memberi arahan dan saran dalam melaksanakan penelitian ini. Terima ka- sih kepada pimpinan Jurusan Kimia FMIPA UNJ dan tim dosen Kimia Organikdan Kimia Bahan Alam, atas kerjasamanya dalam melaksanakan penelitian ini. Harapan kami semoga penelitian ini bermanfaat bagi mahasiswa yang terlibat, khususnya dalam peningkatan kualitas pembelajaran kimia bahan alam.

\section{DAFTAR PUSTAKA}

Anderson, L.W. \& Krathwohl, D.R. 2001. A Taxonomy for Learning, and Assessing: A Revision of Bloom's Taxonomy of Educational Objectives. New York: Longman.

Good, Thomas L., Jere E. Biophy. 1990. Educational Psychology. London: Longman.

Kember, David, 2000. Action Learning and Action Research. London: Kogan Page Limited.

Mann, J. 1980. Secondary Metabolism. Oxford Univercity Press.

Mujiono, Dimyati, 2006. Belajar dan Pembelajaran. Jakarta: PT. Rineka Cipta.

Paolo, Manito. 1992. Biosintesis Produk Alam. IKIP Semarang Presss.

Richard, Arends, 2006. Belajar untuk Mengajar. Edisi Ketujuh/Buku Dua, (Penterjemah Helly Prajitno S.) Yogyakarta: Pustaka Belajar. 
Sastrawijaya, Trisna, 1988. Proses Belajar Mengajar Kimia. Jakarta: Departemen Pendidikan dan Kebudayaan.

Sastrohamidjojo, Harjono. 1992. Sintesis Bahan Alam.Yogyakarta: Gajah Mada University press. 